\title{
Effect of FYM and Zinc Application on Soil Nutrient availability, Soil enzyme activity and Nutrient Content and yield of Barley under Irrigation with Different Residual Sodium Carbonate Waters
}

\author{
Prerna Dogra*, B. L. Yadav, Ramswaroop Jat and Shyopal Jat
}

\author{
Department of Soil Science and Agricultural Chemistry, Sri Karan Narendra Agriculture \\ University, Jobner (Jaipur), Rajasthan, 303329, India \\ *Corresponding author
}

\section{A B S T R A C T}

Keywords

RSC water,

Zinc,

Barley,

FYM,

Soil dehydrogenase

enzyme,

Nutrient content,

Yield

Article Info

Accepted:

19 April 2017

Available Online:

10 May 2017
Field experiment was conducted to work out the effect of different residual sodium carbonate (RSC) waters, FYM and zinc fertilization on soil nutrient availability, soil enzyme activity, nutrient content and yield of Barley on loamy sand soil during rabi seasons of 2013-14 and 2014-15. The treatments were: Three levels of RSC waters (control, 5 and $10 \mathrm{mmol} \mathrm{L-1}$ ), two levels of FYM (control and $15 \mathrm{t}$ ha-1) in main plot and four levels of zinc (control, 15, 30 and $45 \mathrm{~kg}$ ZnSO4 ha-1) in sub-plot. Result revealed that under irrigation with high RSC (10 mmol L-1) of irrigation water the soil available N, P2O5 and $\mathrm{K} 2 \mathrm{O}$ content, soil enzyme activity, nutrient content viz., $\mathrm{P}, \mathrm{K}, \mathrm{Ca}, \mathrm{Mg}$ and $\mathrm{Zn}$ and yield of grain and straw of barley was decreased significantly. Application of $15 \mathrm{t}$ FYM ha-1 showed significant improvement in soil available $\mathrm{N}, \mathrm{P} 2 \mathrm{O} 5, \mathrm{~K} 2 \mathrm{O}$, soil dehydrogenase enzyme activity at different months, nutrient content (N, P, K, Ca, Mg and $\mathrm{Zn}$ ) and grain and straw yield of barley. The increasing level of $\mathrm{Zn}$ significantly increased the $\mathrm{N}, \mathrm{K}, \mathrm{Zn}, \mathrm{Ca}, \mathrm{Mg}$ content as well as grain and straw yield of barley at harvest, while, while, $\mathrm{P}, \mathrm{Na}$ concentration in grain and straw were decreased significantly.

\section{Introduction}

In many parts of arid and semi-arid regions, ground water which is often of poor quality is used as a major source of irrigation. The continuous use of such water for irrigation creates salinity or sodicity in the soil. The soil degradation due to salinity and sodicity problems has affected larger areas of fertile tracts, particularly in arid and semi-arid regions of country and caused significant losses to crop productivity (Yadav, 2003). At present about 6.73 million hectare (Mha) salt affected soils exist in India. Out of which 2.96
Mha are saline and remaining 3.77 Mha are characterized as sodic soils (Anonymous, 2016). As regards to underground water quality in Rajasthan state, only $16 \%$ is good, $16 \%$ marginal and $68 \%$ is of poor quality, whereas, under poor quality water category, distribution of saline, sodic and saline sodic waters are about 16, 35 and $49 \%$, respectively (Sen, 2003).

The role of FYM in promoting reclamation of sodic soils through improvement of soil physical conditions, greater mobilization of 
native $\mathrm{Ca}$, reduction in $\mathrm{pH}$ and enhancement of biological activities is well known. All this could be achieved through use of technology and inputs. The organic supplementations not only meet the nutrient requirements of plant but also sustain microbial activity, catalyzing crop production. Organic manures also, catalyzing mitigate the adverse effect of alkalinity which develops due to use of high RSC irrigation water, by means of increasing aeration, permeability and infiltration rate of soil (Abbas and Fadul, 2013).

Soil enzymatic activity are typically concentrated in the top few centimetres of soil (Murphy et al., 1998) changes in chemistry near the surface (such as increased salinity or sodicity) could greatly affect soil enzymatic activity. The nutrient transformation processes in soil are governed by enzymatic activity, which plays an important role in the initial stages of oxidation of organic matter of the soil. It also helps in improving soil structure, which is required for sustaining crop productivity as well as soil health.

In India, Zinc is now considered the fourth most important yield-limiting nutrient after nitrogen, phosphorus and potassium, respectively (Arunachalam et al., 2013). Zinc deficiency in soils of India is likely to increase from 49 to $63 \%$ by the year 2025 as most of the marginal soils brought under cultivation are showing zinc deficiency (Singh, 2006). Continuous use of high RSC water increases the ESP and $\mathrm{pH}$ of soil which decreases the availability of $\mathrm{Zn}$. As the soil $\mathrm{pH}$ increase, the ionic form of $\mathrm{Zn}$ is changed to hydroxide form, which is insoluble and unavailable to plants. Although the high RSC water can be used successfully by applying higher doses of zinc sulphate, zinc helps in inducing alkalinity tolerance in crop by enhancing its efficiency in utilizing $\mathrm{K}, \mathrm{Ca}$ and $\mathrm{Mg}$ and decreases the adverse effect of sodicity (Shukla and Mukhi, 1980), however, no systematic study has been conducted on application of zinc to soils irrigated with high RSC water in the region. The present investigation was, therefore, undertaken to study the effect of FYM and zinc application on soil properties, build-up of microbial biomass and yield of barley under irrigation with varying levels of RSC water.

\section{Materials and Methods}

The experiment was conducted at the Agronomy Farm, Sri Karan Narendra Agriculture College, Jobner during rabi 20132014 and 2014-15. The site is situated at $26 \circ 05 \mathrm{~N}$ latitude and $75 \circ 28 \mathrm{E}$ longitude at an altitude of $427 \mathrm{~m}$ above mean sea level. The region falls under agroclimatic zone of Rajasthan zone III-A (semi arid eastern plain). The experimental soil (0.0-0.15 m depth) had pHs 8.10, ECe $2.56 \mathrm{dS} \mathrm{m}-1$, organic carbon $1.80 \mathrm{~g} \mathrm{~kg}-1$, available $\mathrm{N} 133.60 \mathrm{~kg}$ ha- 1 , available P $9.48 \mathrm{~kg}$ ha-1, available K 159.15 $\mathrm{kg}$ ha-1 and available $\mathrm{Zn} 0.38 \mathrm{ppm}$. The experiment was laid out in a split block design with 24 treatment combinations of three levels of RSC waters, two levels of FYM and four levels of $\mathrm{ZnSO} 4$ with four replications. The RSC waters were synthesized by dissolving required quantities of $\mathrm{NaCl}, \mathrm{Na} 2 \mathrm{SO} 4, \mathrm{NaHCO} 3, \mathrm{CaCl} 2$ and $\mathrm{MgSO} 4$ in base water of $2.5 \mathrm{mmol} \mathrm{L-1}$. To check the lateral movement of water and salts, buffer strips around each irrigation channel were kept. The RSC water levels were 2.5 (base water), 5.0 and $10.0 \mathrm{mmol}$ L-1. Nitrogen was applied as per recommended dose of $100 \mathrm{~kg} \mathrm{~N}$ ha-1. The farmyard manure was applied @ 15 t ha- 1 . The farmyard manure contained $16.40 \%$ total carbon, $0.55 \%$ $\mathrm{N}, 0.25 \% \mathrm{P}, 0.51 \% \mathrm{~K}$ and had a $\mathrm{C}: \mathrm{N}$ ratio of 29.7. The FYM was applied 15 days before sowing of crop. Half of $\mathrm{N}$ as per treatment through urea was applied as basal. The remaining half dose of $\mathrm{N}$ was applied before first irrigation. Grain and straw yield were 
recorded at harvest, after complete drying the produce of individual plot was weighed before threshing and the weight recorded as biological yield. After recording the biological yield, the material was threshed manually and winnowed. The clean grains obtained from individual plots were weighed and the weight recorded as grain yield. Straw yield was obtained by subtracting the grain yield from biological yield. The grain and straw yield recorded under each plot were converted into quintals per hectare. Soil samples $(0-15 \mathrm{~cm})$ were collected before sowing and after harvesting of the crop from net plots for the study of chemical and biological properties viz. available N, P2O5, $\mathrm{K} 2 \mathrm{O}$, dehydrogenase, alkaline phosphatase and microbial $\mathrm{C}, \mathrm{N}$ and $\mathrm{P}$ with the help of standard methods. All the replicated data obtained from the experiments for consecutive two years of study were statistically analysed using F-test (Gomez and Gomez, 1984). Least significant difference (LSD) values at $\mathrm{p}=0.05$ were used to determine the significance of differences between treatment means.

\section{Results and Discussion}

\section{Available nutrient status of soil}

The data presented in Table 1 reveals that the available $\mathrm{N}, \mathrm{P}$ and $\mathrm{K}$ content of soil after harvest stage of crop decreased significantly with increasing levels of RSC in irrigation water during both the years as well as in pooled analysis. Availability of $\mathrm{N}, \mathrm{P}$ and $\mathrm{K}$ decreased with increased levels of RSC in water could be due to high $\mathrm{pH}$ of soil. As soil $\mathrm{pH}$ increased, biological activity becomes low, which is not conducive for organic matter and its mineralization in soil. Transformations are adversely affected by high $\mathrm{pH}$ and sodicity. High soil $\mathrm{pH}$ coupled with poor physical conditions also adversely affects the transformations and availability of nutrients in soil. The results are in close agreement with the findings of Singh et al., (2005) and Yaduvanshi (2015).

\section{Soil enzyme activity}

Data given in table 2 reveal that activity of dehydrogenase enzyme were also significantly lowered with increasing level of RSC over normal water and with intervals of time, the reduced dehydrogenase activity in sodic soils due to reduction of organic matter in sodic condition and indirect effect of the structural decline of the sodic soil. Similar results were reported by Pareek and Yadav (2011).

\section{Plant Nutrient content}

Data in table 3 and 4 reveals that $\mathrm{N}$ and $\mathrm{Na}$ content in grain and straw increased significantly, while $\mathrm{P}, \mathrm{K}, \mathrm{Ca}, \mathrm{Mg}$ and $\mathrm{Zn}$ content decreased significantly with increasing level of RSC in irrigation water in pooled. The increase in levels of RSC water resulted into increased concentration of $\mathrm{Na}$ in soil solution and on adsorbing complex which caused an increase in ESP and pHs of soil and also of marked increased in $\mathrm{Na}$ content in grain and straw of barley. Further, under higher sodic conditions, the activity of nitrifying bacteria lower down or checked which results into low availability of $\mathrm{N}$ to the plant causing stunted growth and development of plant. According to Strogonov and Okinia (1961), the $\mathrm{N}$ taken up by plants is not utilized and gets accumulated in organs as protein and not available for plant growth, leading to increased content of $\mathrm{N}$ in grain and straw. Contrary, the $\mathrm{P}$ and $\mathrm{K}$ content in grain and straw decreased due to increasing levels of RSC in irrigation water. This might be due to the fact that increasing RSC water increased $\mathrm{pH}$ of soil. 
Table.1 Effect of RSC water, FYM and Zinc levels on available $\mathrm{N}, \mathrm{P}_{2} \mathrm{O}_{5}$ and $\mathrm{K}_{2} \mathrm{O}$ content in soil after harvest of crop

\begin{tabular}{|c|c|c|c|c|c|c|c|c|c|}
\hline \multirow[t]{2}{*}{ Treatments } & \multicolumn{3}{|c|}{ Available $\mathrm{N}\left(\mathrm{kg} \mathrm{ha}^{-1}\right)$} & \multicolumn{3}{|c|}{ Available $\mathrm{P}_{2} \mathrm{O}_{5}\left(\mathrm{~kg} \mathrm{ha}^{-1}\right)$} & \multicolumn{3}{|c|}{ Available $\mathrm{K}_{2} \mathrm{O}\left(\mathrm{kg} \mathrm{ha}^{-1}\right)$} \\
\hline & 2013-14 & 2014-15 & Pooled & $2013-14$ & $2014-15$ & Pooled & $2013-14$ & $2014-15$ & Pooled \\
\hline \multicolumn{10}{|l|}{ RSC levels } \\
\hline $\mathrm{W}_{1}\left(2.5 \mathrm{mmol} \mathrm{L}^{-1}\right)$ & 136.46 & 136.84 & 136.65 & 20.38 & 20.38 & 20.38 & 230.93 & 230.94 & 230.94 \\
\hline $\mathrm{W}_{2}\left(5 \mathrm{mmol} \mathrm{L}^{-1}\right)$ & 133.12 & 133.50 & 133.31 & 19.26 & 19.26 & 19.26 & 229.19 & 229.19 & 229.19 \\
\hline $\mathrm{W}_{3}\left(10 \mathrm{mmol} \mathrm{L}^{-1}\right)$ & 125.12 & 125.50 & 125.31 & 15.29 & 15.30 & 15.29 & 223.60 & 223.61 & 223.60 \\
\hline $\mathrm{SEm}+$ & 0.67 & 0.71 & 0.49 & 0.11 & 0.19 & 0.11 & 1.15 & 1.47 & 0.93 \\
\hline $\mathrm{CD}(\overline{\mathrm{P}}=0.05)$ & 2.03 & 2.13 & 1.41 & 0.32 & 0.58 & 0.32 & 3.45 & 4.43 & 2.69 \\
\hline \multicolumn{10}{|l|}{ FYM levels } \\
\hline $\mathrm{F}_{0}$ (Control) & 129.30 & 129.68 & 129.49 & 17.39 & 17.39 & 17.39 & 224.19 & 224.20 & 224.20 \\
\hline$F_{1}\left(15 \mathrm{tha}^{-1}\right)$ & 133.83 & 134.21 & 134.02 & 19.23 & 19.24 & 19.24 & 231.62 & 231.63 & 231.63 \\
\hline $\mathrm{SEm} \pm$ & 0.55 & 0.58 & 0.40 & 0.09 & 0.16 & 0.09 & 0.94 & 1.20 & 0.76 \\
\hline $\mathrm{CD}(\overline{\mathrm{P}}=0.05)$ & 1.65 & 1.74 & 1.15 & 0.26 & 0.47 & 0.26 & 2.82 & 3.62 & 2.20 \\
\hline \multicolumn{10}{|l|}{ Zinc levels } \\
\hline $\mathrm{Zn}_{0}($ Control $)$ & 132.26 & 132.42 & 132.34 & 18.17 & 18.18 & 18.17 & 225.78 & 225.93 & 225.86 \\
\hline $\mathrm{Zn}_{15}\left(15 \mathrm{~kg} \mathrm{ZnSO}_{4} \mathrm{ha}^{-1}\right)$ & 132.21 & 132.26 & 132.23 & 18.30 & 18.20 & 18.25 & 228.01 & 228.02 & 228.02 \\
\hline $\mathrm{Zn}_{30}\left(30 \mathrm{~kg} \mathrm{ZnSO}_{4} \mathrm{ha}^{-1}\right)$ & 131.23 & 131.85 & 131.54 & 18.30 & 18.43 & 18.36 & 228.62 & 228.63 & 228.62 \\
\hline $\mathrm{Zn}_{45}\left(45 \mathrm{~kg} \mathrm{ZnSO}_{4} \mathrm{ha}^{-1}\right)$ & 130.56 & 131.26 & 130.91 & 18.48 & 18.44 & 18.46 & 229.21 & 229.08 & 229.15 \\
\hline $\mathrm{SEm} \pm$ & 0.82 & 0.77 & 0.56 & 0.11 & 0.12 & 0.08 & 1.44 & 0.98 & 0.87 \\
\hline $\mathrm{CD}(\overline{\mathrm{P}}=0.05)$ & NS & NS & NS & NS & NS & NS & NS & NS & NS \\
\hline
\end{tabular}

$\mathrm{NS}=$ Non significant at 5\% level of significance 
Table.2 Effect of organic manures, moisture regimes and salinity levels on soil

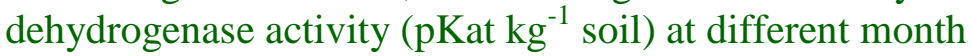

\begin{tabular}{|c|c|c|c|c|c|c|c|c|}
\hline \multirow[t]{2}{*}{ Treatments } & \multicolumn{4}{|c|}{ 2013-14 (month after sowing) } & \multicolumn{4}{|c|}{ 2014-15 (month after sowing) } \\
\hline & $\mathrm{I}$ & II & III & IV & $\mathrm{I}$ & II & III & IV \\
\hline \multicolumn{9}{|l|}{ RSC levels } \\
\hline $\mathrm{W}_{1}\left(2.5 \mathrm{mmol} \mathrm{L}^{-1}\right)$ & 18.43 & 17.50 & 15.96 & 15.14 & 18.63 & 17.56 & 15.92 & 15.22 \\
\hline $\mathrm{W}_{2}\left(5 \mathrm{mmol} \mathrm{L}^{-1}\right)$ & 17.36 & 16.15 & 15.52 & 14.79 & 17.50 & 16.16 & 15.86 & 14.89 \\
\hline $\mathrm{W}_{3}\left(10 \mathrm{mmol} \mathrm{L}^{-1}\right)$ & 14.58 & 13.11 & 11.92 & 10.86 & 14.66 & 13.12 & 12.14 & 10.96 \\
\hline $\mathrm{SEm} \pm$ & 0.09 & 0.11 & 0.08 & 0.07 & 0.12 & 0.11 & 0.09 & 0.08 \\
\hline $\mathrm{CD}(\mathrm{P}=0.05)$ & 0.26 & 0.33 & 0.24 & 0.22 & 0.38 & 0.33 & 0.26 & 0.23 \\
\hline \multicolumn{9}{|l|}{ FYM levels } \\
\hline $\mathrm{F}_{0}$ (Control) & 15.83 & 14.81 & 13.63 & 12.67 & 15.97 & 14.86 & 13.85 & 12.76 \\
\hline $\mathrm{F}_{1}\left(15 \mathrm{tha}^{-1}\right)$ & 17.75 & 16.35 & 15.31 & 14.52 & 17.90 & 16.37 & 15.43 & 14.62 \\
\hline $\mathrm{SEm} \pm$ & 0.07 & 0.09 & 0.06 & 0.06 & 0.10 & 0.09 & 0.07 & 0.06 \\
\hline $\mathrm{CD}(\overline{\mathrm{P}}=0.05)$ & 0.22 & 0.27 & 0.19 & 0.18 & 0.31 & 0.27 & 0.21 & 0.19 \\
\hline \multicolumn{9}{|l|}{ Zinc levels } \\
\hline $\mathrm{Zn}_{0}($ Control $)$ & 16.69 & 15.35 & 14.42 & 13.46 & 16.81 & 15.52 & 14.56 & 13.67 \\
\hline $\mathrm{Zn}_{15}\left(15 \mathrm{~kg} \mathrm{ZnSO}_{4} \mathrm{ha}^{-1}\right)$ & 16.70 & 15.53 & 14.47 & 13.60 & 16.82 & 15.53 & 14.64 & 13.68 \\
\hline $\mathrm{Zn}_{30}\left(30 \mathrm{~kg} \mathrm{ZnSO}_{4} \mathrm{ha}^{-1}\right)$ & 16.81 & 15.72 & 14.49 & 13.66 & 17.01 & 15.69 & 14.66 & 13.69 \\
\hline $\mathrm{Zn}_{45}\left(45 \mathrm{~kg} \mathrm{ZnSO}_{4} \mathrm{ha}^{-1}\right)$ & 16.97 & 15.74 & 14.51 & 13.67 & 17.09 & 15.73 & 14.70 & 13.72 \\
\hline $\mathrm{SEm} \pm$ & 0.11 & 0.13 & 0.09 & 0.10 & 0.13 & 0.12 & 0.10 & 0.09 \\
\hline $\mathrm{CD}(\overline{\mathrm{P}}=0.05)$ & NS & NS & NS & NS & NS & NS & NS & $\mathrm{NS}$ \\
\hline
\end{tabular}


Table.3 Effect of RSC water, FYM and Zinc levels on N, P, K content (\%) in grain and straw after harvest

\begin{tabular}{|c|c|c|c|c|c|c|}
\hline \multirow[t]{2}{*}{ Treatments } & \multicolumn{2}{|c|}{$\begin{array}{c}\mathrm{N} \text { content }(\%) \\
\text { Pooled }\end{array}$} & \multicolumn{2}{|c|}{ P content (\%) Pooled } & \multicolumn{2}{|c|}{ K content (\%) Pooled } \\
\hline & grain & Straw & grain & Straw & grain & Straw \\
\hline \multicolumn{7}{|l|}{ RSC levels } \\
\hline $\mathrm{W}_{1}\left(2.5 \mathrm{mmol} \mathrm{L}^{-1}\right)$ & 0.364 & 0.232 & 0.159 & 0.089 & 0.249 & 0.542 \\
\hline $\mathrm{W}_{2}\left(5 \mathrm{mmol} \mathrm{L}^{-1}\right)$ & 0.339 & 0.200 & 0.148 & 0.079 & 0.267 & 0.663 \\
\hline $\mathrm{W}_{3}\left(10 \mathrm{mmol} \mathrm{L}^{-1}\right)$ & 0.315 & 0.172 & 0.140 & 0.069 & 0.317 & 0.745 \\
\hline $\mathrm{SEm} \pm$ & 0.001 & 0.001 & 0.001 & 0.000 & 0.002 & 0.003 \\
\hline $\mathrm{CD}(\overline{\mathrm{P}}=0.05)$ & 0.004 & 0.003 & 0.002 & 0.001 & 0.005 & 0.009 \\
\hline \multicolumn{7}{|l|}{ FYM levels } \\
\hline $\mathrm{F}_{0}($ Control $)$ & 0.332 & 0.197 & 0.147 & 0.078 & 0.281 & 0.662 \\
\hline $\mathrm{F}_{1}\left(15 \mathrm{tha}^{-1}\right)$ & 0.347 & 0.207 & 0.151 & 0.080 & 0.273 & 0.638 \\
\hline $\mathrm{SEm} \pm$ & 0.001 & 0.001 & 0.001 & 0.000 & 0.001 & 0.003 \\
\hline $\mathrm{CD}(\overline{\mathrm{P}}=0.05)$ & 0.003 & 0.002 & 0.002 & 0.001 & 0.004 & 0.007 \\
\hline \multicolumn{7}{|l|}{ Zinc levels } \\
\hline $\mathrm{Zn}_{0}($ Control $)$ & 0.329 & 0.195 & 0.144 & 0.076 & 0.287 & 0.677 \\
\hline $\mathrm{Zn}_{15}\left(15 \mathrm{~kg} \mathrm{ZnSO}_{4} \mathrm{ha}^{-1}\right)$ & 0.337 & 0.200 & 0.148 & 0.078 & 0.281 & 0.658 \\
\hline $\mathrm{Zn}_{30}\left(30 \mathrm{~kg} \mathrm{ZnSO}_{4} \mathrm{ha}^{-1}\right)$ & 0.345 & 0.205 & 0.152 & 0.081 & 0.274 & 0.636 \\
\hline $\mathrm{Zn}_{45}\left(45 \mathrm{~kg} \mathrm{ZnSO}_{4} \mathrm{ha}^{-1}\right)$ & 0.346 & 0.206 & 0.153 & 0.082 & 0.268 & 0.630 \\
\hline $\mathrm{SEm} \pm$ & 0.002 & 0.232 & 0.001 & 0.000 & 0.001 & 0.003 \\
\hline $\mathrm{CD}(\overline{\mathrm{P}}=0.05)$ & 0.005 & 0.200 & 0.002 & 0.001 & 0.004 & 0.009 \\
\hline
\end{tabular}


Table.4 Effect of RSC water, FYM and Zinc levels on $\mathrm{Ca}, \mathrm{Mg}, \mathrm{Na}, \mathrm{Zn}$ content (\%) in grain and straw after harvest

\begin{tabular}{|c|c|c|c|c|c|c|c|c|}
\hline \multirow[t]{2}{*}{ Treatments } & \multicolumn{2}{|c|}{$\begin{array}{l}\text { Ca content }(\%) \\
\text { Pooled }\end{array}$} & \multicolumn{2}{|c|}{ Mg content (\%) Pooled } & \multicolumn{2}{|c|}{$\begin{array}{l}\text { Na content }(\%) \\
\text { Pooled }\end{array}$} & \multicolumn{2}{|c|}{$\begin{array}{l}\text { Zn content }(\%) \\
\text { Pooled }\end{array}$} \\
\hline & grain & Straw & grain & Straw & grain & Straw & grain & Straw \\
\hline \multicolumn{9}{|l|}{ RSC levels } \\
\hline $\mathrm{W}_{1}\left(2.5 \mathrm{mmol} \mathrm{L}^{-1}\right)$ & 0.364 & 0.232 & 0.159 & 0.089 & 0.249 & 0.542 & 44.58 & 34.08 \\
\hline $\mathrm{W}_{2}\left(5 \mathrm{mmol} \mathrm{L}{ }^{-1}\right)$ & 0.339 & 0.200 & 0.148 & 0.079 & 0.267 & 0.663 & 44.32 & 34.11 \\
\hline $\mathrm{W}_{3}\left(10 \mathrm{mmol} \mathrm{L}^{-1}\right)$ & 0.315 & 0.172 & 0.140 & 0.069 & 0.317 & 0.745 & 43.16 & 32.70 \\
\hline $\mathrm{SEm} \pm$ & 0.001 & 0.001 & 0.001 & 0.000 & 0.002 & 0.003 & 0.19 & 0.15 \\
\hline $\mathrm{CD}(\overline{\mathrm{P}}=0.05)$ & 0.004 & 0.003 & 0.002 & 0.001 & 0.005 & 0.009 & 0.55 & 0.43 \\
\hline \multicolumn{9}{|l|}{ FYM levels } \\
\hline $\mathrm{F}_{0}$ (Control) & 0.332 & 0.197 & 0.147 & 0.078 & 0.281 & 0.662 & 43.50 & 33.12 \\
\hline $\mathrm{F}_{1}\left(15 \mathrm{tha}^{-1}\right)$ & 0.347 & 0.207 & 0.151 & 0.080 & 0.273 & 0.638 & 44.53 & 34.14 \\
\hline $\mathrm{SEm} \pm$ & 0.001 & 0.001 & 0.001 & 0.000 & 0.001 & 0.003 & 0.15 & 0.12 \\
\hline $\mathrm{CD}(\overline{\mathrm{P}}=0.05)$ & 0.003 & 0.002 & 0.002 & 0.001 & 0.004 & 0.007 & 0.45 & 0.35 \\
\hline \multicolumn{9}{|l|}{ Zinc levels } \\
\hline $\mathrm{Zn}_{0}($ Control $)$ & 0.329 & 0.195 & 0.144 & 0.076 & 0.287 & 0.677 & 43.05 & 33.13 \\
\hline $\mathrm{Zn}_{15}\left(15 \mathrm{~kg} \mathrm{ZnSO}_{4} \mathrm{ha}^{-1}\right)$ & 0.337 & 0.200 & 0.148 & 0.078 & 0.281 & 0.658 & 43.72 & 33.30 \\
\hline $\mathrm{Zn}_{30}\left(30 \mathrm{~kg} \mathrm{ZnSO}_{4} \mathrm{ha}^{-1}\right)$ & 0.345 & 0.205 & 0.152 & 0.081 & 0.274 & 0.636 & 44.55 & 33.96 \\
\hline $\mathrm{Zn}_{45}\left(45 \mathrm{~kg} \mathrm{ZnSO}_{4} \mathrm{ha}^{-1}\right)$ & 0.346 & 0.206 & 0.153 & 0.082 & 0.268 & 0.630 & 44.75 & 34.13 \\
\hline $\mathrm{SEm} \pm$ & 0.002 & 0.232 & 0.001 & 0.000 & 0.001 & 0.003 & 0.20 & 0.15 \\
\hline $\mathrm{CD}(\overline{\mathrm{P}}=0.05)$ & 0.005 & 0.200 & 0.002 & 0.001 & 0.004 & 0.009 & 0.56 & 0.42 \\
\hline
\end{tabular}


Int.J.Curr.Microbiol.App.Sci (2017) 6(5): 2078-2089

Table.5 Effect of RSC water, FYM and Zinc levels on grain and straw yield (q ha $\left.{ }^{-1}\right)$ of barley

\begin{tabular}{|c|c|c|c|c|c|c|}
\hline \multirow[t]{2}{*}{ Treatments } & \multicolumn{3}{|c|}{ Grain yield } & \multicolumn{3}{|c|}{ Straw yield } \\
\hline & 2013-14 & 2014-15 & Pooled & 2013-14 & 2014-15 & Pooled \\
\hline \multicolumn{7}{|l|}{ RSC levels } \\
\hline 0 & 44.84 & 46.45 & 45.64 & 65.56 & 66.36 & 65.96 \\
\hline 5 & 43.87 & 45.49 & 44.68 & 64.82 & 65.89 & 65.35 \\
\hline 10 & 37.05 & 38.81 & 37.93 & 58.31 & 59.03 & 58.67 \\
\hline $\mathrm{SEm} \pm$ & 0.61 & 0.71 & 0.47 & 0.93 & 0.94 & 0.66 \\
\hline $\mathrm{CD}(\overline{\mathrm{p}}=0.05)$ & 1.84 & 2.15 & 1.35 & 2.80 & 2.83 & 1.91 \\
\hline \multicolumn{7}{|l|}{ FYM levels } \\
\hline 0 & 40.36 & 42.10 & 41.23 & 61.34 & 62.14 & 61.74 \\
\hline 15 & 43.49 & 45.07 & 44.28 & 64.45 & 65.37 & 64.91 \\
\hline $\mathrm{SEm} \pm$ & 0.50 & 0.58 & 0.38 & 0.76 & 0.77 & 0.54 \\
\hline $\mathrm{CD}(\overline{\mathrm{p}}=0.05)$ & 1.50 & 1.75 & 1.11 & 2.29 & 2.31 & 1.56 \\
\hline \multicolumn{7}{|l|}{ Zinc levels } \\
\hline 0 & 40.52 & 42.13 & 41.32 & 59.94 & 60.92 & 60.43 \\
\hline 15 & 41.55 & 43.19 & 42.37 & 61.70 & 62.42 & 62.06 \\
\hline 30 & 42.64 & 44.56 & 43.60 & 64.81 & 65.76 & 65.29 \\
\hline 45 & 42.99 & 44.46 & 43.72 & 65.13 & 65.93 & 65.53 \\
\hline $\mathrm{SEm} \pm$ & 0.49 & 0.61 & 0.39 & 0.90 & 0.75 & 0.58 \\
\hline $\mathrm{CD}(\overline{\mathrm{p}}=0.05)$ & 1.37 & 1.73 & 1.09 & 2.53 & 2.12 & 1.63 \\
\hline
\end{tabular}


The resulted higher sodicity of the soil could have decreased the mobility of $\mathrm{P}$ due to presence of $\mathrm{Na}$. At higher $\mathrm{pH}$, the proportions of HPO4-2 and PO43- have increased over $\mathrm{H} 2 \mathrm{PO} 4-$. The presence of $\mathrm{OH}-$ ions, the availability of $\mathrm{P}$ to the plant is reduced. The physiological availability of $\mathrm{P}$ in alkali soil is a fraction of $\mathrm{pH}$ and it decreases as the $\mathrm{pH}$ increase over the alkaline range (Pratt and Thorne, 1948 and Sauchelli, 1965). Further, the decrease in content of $\mathrm{K}$ in grain and straw of barley as influenced by various levels of exchangeable sodium, increased $\mathrm{Na}$ saturation of soil was accompanied by an extensive depletion of $\mathrm{K}$ in plant (Moustafa $e t$ al., 1966). This can be explained on the basis of hypothesis of Heimann (1958) who was of the view that $\mathrm{Na}-\mathrm{K}$ relationship may be synergistic or antagonistic depending upon the ratio between them. The decrease in $\mathrm{K}$ content in grain and straw of barley with an increase in RSC in irrigation water was also reported by Singh et al., (2005) and Mahmood (2011). The $\mathrm{Ca}$ and Mg content of both grain and straw decreased significantly with increasing levels of RSC in irrigation water. This may be due to the fact that the increase in $\mathrm{Na}$ concentration, either in soil solution or on adsorbing complex owing to precipitation of $\mathrm{Ca}$ and $\mathrm{Mg}$ into sparingly soluble $\mathrm{CaCO} 3$ and $\mathrm{MgCO} 3$, thus, decreases its availability to crop plants. The increasing levels of RSC in irrigation water decreased the $\mathrm{Zn}$ in grain and straw, might be due to the fact that increased alkali concentration decreased in the $\mathrm{Zn}$ content may be ascribed to the conversion of $\mathrm{Zn} 2+$ to its unavailable form under sodic environment generated by high RSC water. Similar findings were also reported by, Yadav (1999), Jatav (2000) and Yadav (2001) and Jakhar et al., (2013).

The $\mathrm{N}, \mathrm{P}, \mathrm{K}, \mathrm{Ca}, \mathrm{Mg}$ and $\mathrm{Zn}$ content in grain and straw of barley increased significantly, whereas $\mathrm{Na}$ content in grain and straw decreased significantly with application of
FYM @ 15 t ha-1 in pooled analysis (Table 3 to 4). The higher content of nutrients in grain and straw of barley may be attributed to increased available nutrient status of soil due to application of FYM. The improvement in properties of soil as observed in the present study (Table 2) coupled with steady and slow release of macro and micro nutrients during microbial decomposition of FYM increased the available nutrient pool of soil. As stated earlier, under higher availability of nutrients, the plants absorbed nutrients liberally without any hindrance which resulted in improved photosynthesis, production of assimilates and their efficient partitioning into different sinks resulting into higher nutrient content of grain and straw. The decrease in $\mathrm{Na}$ content of grain and straw was a consequence of lesser availability of $\mathrm{Na}$ in soil solution due to reduction in ESP under increased application of FYM which resulted in decreased absorption by plants and ultimately the content. The decrease in $\mathrm{Na}$ concentration in grain and straw of barley have also been reported by Poonia and Bhumbla (1974). The findings of the present investigation get support from the results of Singh and Singh (2001), Sharma and Sharma (2002) and Mann et al., (2006), who also reported that increase nutrients in grain and straw of barley, may be attributed to increase available nutrient status of soil due to application of FYM under irrigation with high sodic water. The $\mathrm{N}, \mathrm{K}$, $\mathrm{Ca}, \mathrm{Mg}$ and $\mathrm{Zn}$ content in grain and straw of barley increased significantly with increasing level of zinc upto $30 \mathrm{~kg} \mathrm{ZnSO} 4$ ha-1 in pooled analysis (Table 3 to 4 ). The $\mathrm{P}$ and $\mathrm{Na}$ content decreased significantly with increasing level of zinc in pooled analysis. The significant response of barley to zinc is due to low status of $\mathrm{Zn}$ availability in experimented soil and alkalinity of soil. The low magnitude of response at higher level of $\mathrm{Zn}$ is due to increase in availability of $\mathrm{Zn}$ at higher level leading to toxic effect of this dose on the adsorption of various nutrients 
which is supported by lower concentration of $\mathrm{P}$ and higher concentration of $\mathrm{Zn}$ in grain and straw. This appears to have caused nutrient imbalance in plant system. The beneficial role of $\mathrm{Zn}$ in increasing CEC of roots helped in increasing adsorption of nutrients from the soil. Further, the beneficial role of $\mathrm{Zn}$ in chlorophyll formation, regulating auxin concentration and its stimulatory effect on most of physiological and metabolic process of plant, might have helped to plants in absorption of greater amount of nutrients from the soil. Thus, the favourable effect of $\mathrm{Zn}$ on photosynthesis and metabolic process augmented the production of photosynthates and their translocation to different plant parts including grain which ultimately increased the concentration of nutrients in the grain. The reduction in the concentration of $\mathrm{P}$ owing to application of $\mathrm{Zn}$ might be due to antagonism relationship of $\mathrm{Zn}$ and $\mathrm{P}$ (Olsen, 1972). The increased concentration of $\mathrm{Zn}$ created hindrance in absorption and translocation of $\mathrm{P}$ from the roots to the above plant parts (Damodhar Reddy and Yadav, 1994). Ca and $\mathrm{Mg}$ concentration in grain and straw increased with increasing level of $\mathrm{Zn}$. The $\mathrm{Na}$ content in grain and straw decreased with the application of increasing level of $\mathrm{Zn}$, this may be due to the fact that on the exchangeable complex, the $\mathrm{Na}$ will be replaced by $\mathrm{Zn}$ which results into more absorption of $\mathrm{Zn}$ than $\mathrm{Na}$ by plants. This led to the lower concentration of $\mathrm{Na}$ in grain and straw.

\section{Yield}

The grain and straw yield of barley decreased significantly with increase in level of RSC in irrigation water during both the years and also when data were pool (Table 5). This may be explained on the basis that increasing RSC in irrigation water increased the ESP and $\mathrm{pH}$ of soil resulting into decreased availability of $\mathrm{N}$, $\mathrm{P}, \mathrm{K}, \mathrm{Ca}$ and $\mathrm{Mg}$ but increased the content of $\mathrm{Na}$ which is toxic to plant. The higher amount of Na may adversely affect the physiological, metabolic and enzymatic activities and utilization of photosynthates in plant, resulting into poor root development and plant growth and ultimate decrease in yield of barley (Bajwa et al., 1982).

The application of 15 t FYM ha-1 substantially increased the grain and straw yield of barley over control in both the years (Table 5). The increase in yield due to addition of FYM might be the result of overall improvement in soil physicochemical properties of sodic soil due to decrease in $\mathrm{pH}$, EC, and ESP; and increase in saturated hydraulic conductivity and cation exchange capacity. The higher nutrient availability and congenial environment for their uptake favoured greater synthesis of carbohydrates and their efficient portioning into different sinks including reproductive structures which ultimately brought about significant improvement in yield (Abbas and Fadul, 2013). Similar results were also reported by Ghosh and Singh (2003) and Thakur et al., (2011).

The increasing level of $\mathrm{Zn}$ application upto 30 $\mathrm{kg} \mathrm{ZnSO} 4$ ha-1 significantly increased grain and straw yield during both the years and in pooled analysis (Table 5). The favourable influence of applied $\mathrm{Zn}$ on these characters may be explained to its catalytic or stimulatory effect on most of the physiological and metabolic process of plants. Zinc is also an essential component of enzymes that are responsible for assimilation of N. It also helps in chlorophyll synthesis and plays an important role in $\mathrm{N}$ metabolism thereby resulting into increased uptake of $\mathrm{N}$ by the plants. Besides, $\mathrm{Zn}$ also enhances the absorption of essential nutrients by increasing the CEC of roots. The application of zinc in a soil deficient in its status, improved overall growth and development of plants and ultimately the grain and straw yield under 
irrigation with high RSC water (Jakhar et al., 2013). Increase in grain and straw yields due to $\mathrm{Zn}$ application may be attributed to the fact that the initial status of available $\mathrm{Zn}$ in the experimental soil (Table 5) was low and an increase in the yield was expected. These findings of present investigation are supported by Sharma et al., (2002).

\section{References}

Abbas, I.M.I. and Fadul, H.M. 2013. The Effects of Farm Yard Manure (FYM) on Sodic Soil in Gezira-Sudan (Triticum aestivum L.) Production in Gezira-Sudan. J. Agri. Vet. Sci., 14: 11-22.

Anonymous. 2016. Central Soil Salinity Research Institute. (ICAR), Karnal, India.

Arunachalam, P., Kannan, P., Prabukumar, G. and Govindaraj, M. 2013. Zinc deficiency in Indian soils with special focus to enrich zinc in peanut. Academic J., 8: 6681-6688.

Bajwa, M.S., Hira, G.S. and Singh, N.T. 1982. Effect of continuous use of high sodium and bicarbonate waters on soil and crop yields. Transactions of the 12th International Congress of Soil Science, 6: 173.

Damodar Reddy, D. and Yadav, B.R. 1994. Zinc and phosphorus nutrition of wheat grown on a highly calcareous soil. Annals of Arid Zone, 33: 233-238.

Ghosh, B.N. and R.D. Singh. 2003. Effect of conjoin use of farmyard manure and on rice (Oryza sativa) -wheat (Triticum aestivum) system in Uttaranchel mid-hill soils. Indian J. Agric. Sci., 73: 680683.

Gomez, K. and Gomez, A. 1984. Statistical procedure for agriculture research $2 \mathrm{nd} \mathrm{Ed}$. Pub. John Willey and Sons Anc, New York.

Jakhar, R.K., Yadav, B.L. and Choudhary, M.R. 2013. Irrigation water quality and zinc on growth and yield of fenugreek (Trigonella foenumgraecum L.). J. Spices aromatic Crop, 22: 170-173.
Mahmood, K. 2011. Salinity tolerance in Barley (Hordeum Vulgare L.): Effects of varying $\mathrm{NaCl}, \mathrm{K}+/ \mathrm{Na}+$ and $\mathrm{NaHCO} 3$ levels on cultivars differing in tolerance. Pak. J. Bot., 43: 1651-1654.

Moustafa, A.H.I., Shabassay, A.I. and Gohar, A.I. 1966. Growth and cationic accumulation by wheat and barley plants as influenced by various levels of exchangeable sodium. Agric. Res. Rev., (Cairo). 44: 1-17.

Murphy, D.V., Sparling, G.P. and Fillery, I.R.P. 1998. Stratification of microbial biomass $\mathrm{C}$ and $\mathrm{N}$ and gross $\mathrm{N}$ mineralization with soil depth in two contrasting Western Australian agricultural soils. Australian J. Soil Res., 36: 45-55.

Olsen, S.R. 1972. Micronutrient Interactions. In: Micronutrients in Agriculture, Mortved, J.M.J.J., P.M. Goirdano and W.L. Lindsay (Eds.). Soil Science Society of America, Madison, WI., pp: 243-264.

Pareek, N. and Yadav, B.L. 2011. Effect of orgnaic manure on soil physio-chemical properties, soil microbial biomass and yield of mustard under irrigation of different residual sodium carbonate water. J. Indian Soc. Soil Sci., 59: 336-342.

Pratt, P.F. and Thorne, D.W. 1948. Sodicity and availability of phosphate in sodium and calcium system. Soil Sci., 13: 213-217.

Sauchelli, V. 1965. Phosphate in agriculture. Reinhold publishing corporation, New York.

Sharma, S.P., Subehia, S.K. and Sharma, P.K. 2002. Long-term effects of chemical fertilizers on soil quality, crop productivity and sustainability. Research Bulletin. CSK Himachal Pradesh Krishi Vishvavidyalya. pp, 33.

Shukla, U.C. and Mukhi, A.K. 1980. The ameliorative role of zinc on the growth of maize (Zea mays L.) under salt-affected soil conditions. International Symposium on Salt-affected Soils, CSSRI, Karnal, pp 362-368.

Singh, M.V. 2006. Micronutrients in crops and in soils of India. In: Alloway B.J (ed.) 
Micronutrients for global crop production. Springer, Business.

Singh, P.K., Pal, V., Pandey Manoj and Singh, A.K. 2005. Effect of irrigation water containing RSC on the yield, chemical composition and uptake of nutrients by periwinkle leaves, Indian J. Agri. Res., 39: 116- 121.

Strogonov, B.P. and Oknina, E.Z. 1961. Study on the dormancy of plant under conditions of irrigation with sodic solution. Fiziol Cheloveka, 8: 79-85.

Thakur, R., Sawarkar, S.D., Vaishya, U.K. and Singh, M. 2011. Impact of continuous use of inorganic fertilizers and organic manure on soil properties and productivity under soybean - wheat intensive cropping of a vertisol. J. Indian Soc. Soil Sci., 59: 74-81.

Yadav, J.S.P. 2003. Managing soil health for sustained high productivity. J. Indian Soc. Soil Sci., 52: 448-465.

Yaduvnshi, N.P.S. 2015. Nutrient management strategies for sustaining crop production with sodic water. Annals of Plant and Soil Res., 17: 114-124.

\section{How to cite this article:}

Prerna Dogra and Shyopal Jat. 2017. Effect of FYM and Zinc Application on Soil Nutrient availability, Soil enzyme activity and Nutrient Content and yield of Barley under Irrigation with Different Residual Sodium Carbonate Waters. Int.J.Curr.Microbiol.App.Sci. 6(5): 2078-2089. doi: https://doi.org/10.20546/ijcmas.2017.605.232 